\title{
IAMJ
}

INTERNATIONAL

AYURVEDIC

MEDICAL JOURNAL

[]. $(1$

\section{MANAGEMENT OF MADHUMEHA ACCORDING TO AYURVEDA - A CASE STUDY}

\author{
Nitin Bhairavnath Bansode ${ }^{1}$, Prashant Dhanaraj Chandekar ${ }^{2}$, Nilesh Dnyaneshwar Dhumne ${ }^{3}$ \\ ${ }^{1}$ Department of Kaumarbhritya, Smt. Vimladevi Ayurvedic Medical College and Hospital, Wandri, Chandrapur, \\ Maharashtra, India \\ ${ }^{2}$ Department of Sharir Kriya, Vimladevi Ayurvedic Medical College and Hospital, Wandri, Chandrapur, Maha- \\ rashtra, India \\ ${ }^{3}$ Department of Kaumarbhritya, Smt. Vimladevi Ayurvedic Medical College and Hospital, Wandri, Chandrapur, \\ Maharashtra, India
}

Corresponding Author: sukanyawaghmare1998@gmail.com

\section{https://doi.org/10.46607/iamj4008082020}

(Published online: August 2020)

Open Access

(C) International Ayurvedic Medical Journal, India 2020

Article Received: 26/07/2020 - Peer Reviewed: 05/08/2020 - Accepted for Publication: 05/08/2020

\section{Check for updates}

\section{ABSTRACT}

Diabetes mellitus is the disease afflicting mankind since a very long time. Over 30 million people have been diagnosed with Diabetes in India and it is one among the cause for morbidity, which makes the life of individual miserable. In Ayurveda, Diabetes mellitus can be understood as Madhumeha which is one among the Vataja Prameha. Lakshana pertaining to Madhumeha as per the classical text are Prabhoota Mutra, Aavila mutra etc. In the present case study, a 45 years old male patient came to Smt. Vimladevi Ayurvedic Medical College and Hospital OPD with complaints of pain in smaller joints and increased frequency of micturition. Through Physical findings and Investigations, the diagnosis leads to Madhumeha (Diabetes mellitus). The treatment plan opted was Shamana Aushadhi, Proper Diet and Change in Lifestyle would be an apt management in such case.

Keywords: Madhumeha, Diabetes mellitus, Shamana Aushadhi, Lifestyle

\section{INTRODUCTION}

Lifestyle diseases are linked with the way people live their life. With decreasing physical exertion, irregular food habits and sleep patterns, predominantly sedentary lifestyle has led to many Lifestyle disorders, one 
among them is Diabetes. Epidemiological studies of type 2 diabetes provide evidence that overeating, especially when combined with obesity and underactivity, is associated with the development of type 2 diabetes. Globally as of 2019, an estimated 390 million people were diagnosed as Diabetic, with Type 2 diabetes making up about $85 \%$ of the cases. Diabetes mellitus is a group of metabolic disorders characterized by chronic hyperglycemia resulting from defects in insulin secretion, insulin action or both. The high blood sugar produces the symptoms like frequent micturition increased thirst, and increased hunger. Untreated Diabetes can cause many complications. Acute complications include Diabetic ketoacidosis and nonketotic hyperosmolar coma. Serious long-term complications include heart disease, stroke, kidney failure, foot ulcers etc. In Ayurveda Diabetes mellitus is referred to Madhumeha which is a Santarpanajanya vikara and one among the type of Vataja Prameha and grouped under Astamahagada. Due to continuous indulgence in Nidana, it results in Aparipakwa Kapha and Meda, which inturn vitiates kleda and meda further resulting Doshadushyasamoorchana. Kleda remaining after Dhatavagnipaka through the Mootravahasrotas and get localised at Bastimukha and leading to symptoms like Prabhootamutra, Aavilamutra etc. Diabetes cannot be cured, but it can be managed. The management should be very particular because the management should include dietary modification, lifestyle modification and Anti-diabetic drugs. Ayurvedic management includes Samshamana chikitsa and Samshodana chikitsa along with Vyayama.Samshana chikitsa includes some of the Yogas like Asanadi kashaya, Nishamalaki choorna, Madhvasava etc and single drugs like Haridra (Curcuma longum), Amalaki (Emblica officinalis) along with Madhu (honey\}, etc.

Aim and Objectives: To evaluate the efficacy of Ayurvedic medicines in the management of Madhumeha

\section{Materials And Methods}

Present complaints:

A 45 years old Indian, married Male consulted on
08-01-2019 in Smt. Vimladevi Ayurvedic Medical College And Hospital, Wandri, Chandrapur for complaints of pain in smaller joints along with increased frequency of micturition since 1.5 years.

His body weight and height were found to be $68 \mathrm{~kg}$ and $170 \mathrm{~cm}$ respectively.

\section{Patients personal History:}

The patient wakes up at $6.30 \mathrm{am}$ and sleeps at $11 \mathrm{pm}$. $\mathrm{He}$ is a vegetarian, suffering from increased appetite $\&$ disturbed sleep. The micturition frequency was changed from 8-10 times during day \& 4-5 times at night to 3-4 times during day \& 1-2 times at night after the treatment. The patient used to take coffee twice a day before treatment which is replaced to decoction of Fenugreek [Trigonella foenumgraecum] in early morning.

\section{Food Habits:}

Breakfast at $10 \mathrm{am}$ including food prepared of rice items more was changed at 9am with food of foxtail millet \& reduced rice items. The lunch timing was changed from $2 \mathrm{pm}$ to $1 \mathrm{pm}$ with freshly prepared food items and the dinner at $9.30 \mathrm{pm}$ with ragi balls, sambar, rice was shifted to $8.30-8.45 \mathrm{pm}$ with ragi balls, sambar/chapathi.

\section{General Examination:}

During general examination, patient was found conscious with Normal general appearance \& gait and Moderate built. The Pollar, Icterus, Cyanosis, Clubbing, Oedema \& Lymphadenopathy was found to be Absent.

\section{Dashavidha Pareeksha:}

The results of Dashavidha Pareeksha was found as Madhyama for Sara, Samhanana, Satmya, Satva, Pramana, Adhara, Shakthi, Vyayama Shakthi \& Vaya. The Tridosha ; Dushya includes medha, raktha, sukra, ambu, vasa, lasika, majja, rasa, ojas, mamsa.

The Prakriti and Vikriti-Dosha was found as Vata kapha \& Vata pradhana respectively.

\section{Investigations:}

It includes

- FBS, FUS, PPBS, PPUS, RBS 
Diagnosis - On the basis of symptoms the patient is diagnosed with Madhumeha (Diabetes mellitus)

Treatment Plan

Details explained in the Table3.

Table 3 Treatment

\begin{tabular}{ll}
\hline Date & Medication \\
\hline 08.01 .2019 TO & Asanadi gana \\
08.06 .2019 & kashaya3tsf TID \\
& Goranchi 2-0-2 \\
& Dibizide 1-0-0
\end{tabular}

Slight Modification in the Treatment plan

\begin{tabular}{|c|c|}
\hline $\begin{array}{l}15.07 .2019 \text { to } \\
14.09 .2019\end{array}$ & $\begin{array}{l}\text { Asanadi gana } \\
\text { kashaya3tsf TID } \\
\text { Nishamalaki2-0-2 } \\
\text { Dibizide1-0-0 }\end{array}$ \\
\hline $\begin{array}{l}29.10 .2019 \text { to } \\
01.01 .2020\end{array}$ & $\begin{array}{l}\text { Asanadi gana kashaya } \\
3 \text { tsf TID } \\
\text { Nishamalaki2-0-2 }\end{array}$ \\
\hline 29.04 .2020 & $\begin{array}{l}\text { Asanadi gana kashaya } \\
\text { 3tsf TID } \\
\text { Nishamalaki2-0-2 }\end{array}$ \\
\hline
\end{tabular}

Investigation

Details discussed in the Table 4

Table 4 Investigations

\begin{tabular}{|c|c|c|}
\hline Date & $\begin{array}{c}\text { FBS/ } \quad \text { PPBS/PP } \\
\text { FUS US }\end{array}$ & RBS/RUS \\
\hline 08/01/19 & $\begin{array}{ll}285.2 & 330.5 \\
\mathrm{Mg} / \mathrm{dl} & \mathrm{Mg} / \mathrm{dl} \\
2.0 \% & 2.0 \%\end{array}$ & \\
\hline 07/04/19 & - & $\begin{array}{l}293 \mathrm{mg} / \mathrm{dl} \\
2 \%\end{array}$ \\
\hline $30 / 05 / 19$ & - & $\begin{array}{l}155.5 \mathrm{mg} / \mathrm{dl} \\
\text { RUS- } \\
\text { Absent }\end{array}$ \\
\hline $15 / 08 / 19$ & $\begin{array}{ll}106.5 & 158 \\
\mathrm{Mg} / \mathrm{dl} & \mathrm{Mg} / \mathrm{dl} \\
\text { Absent } & \text { Absent }\end{array}$ & \\
\hline $\begin{array}{l}22 / 09 / 20 \\
19\end{array}$ & $\begin{array}{l}99.4 \\
\mathrm{mg} / \mathrm{dl} \\
\text { Absent }\end{array}$ & \\
\hline
\end{tabular}




\begin{tabular}{lrr}
\hline $16 / 11 / 20$ & 228.2 & 287.1 \\
19 & $\mathrm{mg} / \mathrm{dl}$ & $\mathrm{mg} / \mathrm{dl}$ \\
& $1.5 \%$ & $2.0 \%$
\end{tabular}

$189.7 \mathrm{mg} / \mathrm{dl}$

20

\begin{tabular}{lll}
\hline $15 / 04 / 20$ & 105.6 & 180.5 \\
20 & $\mathrm{mg} / \mathrm{dl}$ & $\mathrm{mg} / \mathrm{dl}$ \\
& Abse & $0.5 \%$ \\
$\mathrm{nt}$ &
\end{tabular}

$29 / 05 / 20 \quad 250.2 \quad 314.4$

$20 \quad \mathrm{mg} / \mathrm{dl} \mathrm{mg} / \mathrm{dl}$

$1.5 \% \quad 2.0 \%$

$15 / 06 / 20$

$155.8 \mathrm{mg} / \mathrm{dl}$

\section{Results}

Improvement in subjective signs and symptoms was found as mentioned in the Table 5.

- Increased frequency of micturition (Prabhoota mutra) was decreased.

- Marked reduction in the Blood sugar level.

Table 5: Results

\begin{tabular}{|lll|}
\hline Physical finding & Before treatment & After treatment \\
\hline Frequency of & $8-10$ times during day & $3-4$ times during daytime \\
\hline micturation & $4-5$ times at night & $1-2$ times at night \\
\hline Weakness & Present & Absent \\
\hline
\end{tabular}

\section{Investigations}

Date

08/01/2019-

$15 / 06 / 2020$

\section{DISCUSSION}

The present study includes medications like Asanadi Kashaya, Nishamalaki, Tab Gornachi where Asanadi gana kashaya include drugs like Asana (Pterocarpus marsupium), Tinisha (Ogeinia dalbergioides), Bhurja (Betula utilis), Meshahringi (Gymnema sylvestre), Daruharidra (Berberis aristata) etc.It is indicated in Prameha, Medo dosa and Kapha vikara. Most of the drugs have Kashaya rasa, Laghu ruksha guna, Sheeta virya and Katu vipaka. Mainly acts on Kaphadosha. Nishamalaki tablet contains Nisha (Haridra) [Curcuma longa], Amalaki (Phyllanthus emblica), Nimba
After treatment

RBS/RUS- 155.5 mg/dl, Absent

patra (Azadirachta indica), Jambu beeja (Syzygium cumini), Madhunashini (Gymnema sylvestre). All the drugs process

Mehahara karma and it is indicated in Prameha. Goranchi tablet include Madhunashini (Gymnema sylvestre) leaf and root, Jambuphala (Syzygium cumini), Amalaki (Phyllanthus emblica), Haridra (Curcuma longa), Shilajatu. It is Tridoshahara. Most of the ingredients have Mehahara karma and also improves the digestive fire. Treatment is based on Samprapthi of the Vyadi and the Doshas involved. In the present study, Vyadhi is due to Agnimandya and Medodushti 
along with involvement of Kalpha dosa. The medications selected above are based on Vyadhi as well as Dosha involved i.e Vyadhipratyanika \& Doshapratyanika chikitsa. The drugs having Tikta, Kashaya and katu rasa along with Laghu, Ruksha guna and Lekhana Karma plays a major role in the management of santarpanajanya Vikara where Madhumeha is one among them. The drugs mentioned in the above formulations also possess the same properties along with Mehahara Karma, hence the Vyadhipratyanika and Doshapratyanika Chikitsa is established.

\section{CONCLUSION}

From the present study it can be concluded that Ayurvedic management of Madhumeha is better achieved by following the proper dietary food habits, lifestyle along with Shamana Aushadi. The holistic approach of Ayurveda utilising the above concept will definitely pay the way not only to control the blood sugar level and also to prevent the complications caused by Madhumeha.

\section{REFERENCES}

1. Haslett Christopher, Chilvers Edwin R, Hunter John A A, Bonn Nicholas A.(1999). Davidson's Principles And Practice of Medicine. Edinburgh: Churchill Livingstone/Elsevier.

2. Nita Gandhi Frouchi, Nicholas J. Wareham. Medicine (Abingdon)2014 Dec;42(12): 698-702. Doi; 10.1016/j.mpmed.2014.09.007.

3. American diabetes assosciation. Diabetes Care. 2010 jan; 33 (suppl 1): s62-s69. Doi:10.2337/dc10-s062.

4. Acharya Agnivesha; CharakaSamhita; redacted by Charaka and Dridabala with Ayurveda Dipika Commentary by Chakrapani Dutta; deited by Vaidya Yadhavji Trikamji Acharya; $4^{\text {th }}$ Edition; Sutrasthana 23/5 published by Chaukambhu Surabharathi Prakashana Varanasi, 2001;296.

5. Acharya Agnivesha; CharakaSamhita; redacted by Charaka and Dridabala with Ayurveda Dipika Commentary by Chakrapani Dutta; edited by Vaidya Yadhavji TrikamjiAcharya; $4^{\text {th }}$ Edition; published by Chaukambha Surabharathi Prakashana Varanasi, 2001;213.

6. Ajay Kumar Sharma. Kayachikitsa Dvithiya Bhaga 2013. ed. Delhi: Chaukabha Orientali; 2013.p.885-6.
7. Kaviraja Ambikadutta Shastri editor Shushruta Samhita of Sushruta, Chikitsa sthana11/11, Chaukhamba Sanskrit Sansthv, Varanashi, 2003:62.

8. Acharya Vagabhata, Astanga Hridaya with Sarvangasundara commentary of Arundatta, Aurveda Rasayana of Hemadri Edited by pt. Harisadashiva Shastri paradakara Bhishak Acharya Published by Chaukambha Surabharthi Prakashan, Varanasi, reprint 2007 Sutrastana, Chapter15/19-20., page no 236

9. Acharya Vagbhata, Astanga Hridaya with Sarvangasundara commentary of Arundatta, Ayurveda Rasayana of Hemadri Edited By pt Harasadashiva Shastri Paradakara Bhishak Acharya Published by Chaukambha Surabharthi Prakashan, Varanasi, reprint 2007 Chikisthana, Chapter12/5., page no 628.

10. Acharya Agnivesha., Chakrasamhita, redacted by Charaka and Dridabala with Ayurveda Dipika Commentary by Chakrapani Dutta., edited byVaidya Yadavaji Trikamji Acharya., $4^{\text {th }}$ Edition., Chikisasthana 6/41-42, published by Chaukambha Surabharthi Prakashana Varanasi,2001., 513

11. Kaviraja Ambikadatta Shastri editor of Shushruta Samhita, Chikistasthana 11/8, Chaukambha Sanskrit Sansthan, Varanasi, 2003:60.

\section{Source of Support: Nil Conflict of Interest: None Declared}

How to cite this URL: Nitin Bhairavnath Bansode et al: Management Of Madhumeha According To Ayurveda - A Case Study. International Ayurvedic Medical Journal \{online\} 2020 cited August, 2020\} Available from: http://www.iamj.in/posts/images/upload/4278 4282.pdf 